\title{
IMPLEMENTASI PROGRAM PELIBATAN DAN PEMBERDAYAAN MASYARAKAT PT TIRTA INVESTAMA AQUA BABAKAN PARI
}

\section{IMPLEMENTATION OF COMMUNITY ENGAGEMENT AND EMPOWERMENT PROGRAMS PT TIRTA INVESTAMA AQUA BABAKAN PARI}

\author{
Raisatul Janah $^{\mathbf{1}^{*}}$, Sukarelawati ${ }^{2}$, Agustini $^{3}$. \\ ${ }^{123}$ Ps Sains Komunikasi Fakultas Ilmu Sosial dan Ilmu Politik, Universitas Djuanda Bogor, \\ Jl. Tol Ciawi No 1 Kotak Pos 35 Bogor 16770.
}

*Korespondensi: Raisatul Janah, raisatul.janah@unida.ac.id

(Diterima oleh Dewan Redaksi: 01-02-2019)

(Dipublikasikan oleh Dewan Redaksi: 01-04-2019)

\begin{abstract}
This study aims to find out Muslim social behavior towards LGBT in the film Cinta Fiisabiilillah on Youtube. This study used a qualitative approach and descriptive analysis research method by carrying out data collection techniques using primary data and secondary data. Primary data is in the form of observations and interviews. While secondary data is in the form of documentation. The object of research is the Cinta Fiisabiilillah Film. The results showed that Muslim social behavior towards LGBT in the film Cinta Fiisabiilillah was to accept and embrace it to hijrah Fiisabiilillah together and not move away because of its poor past.
\end{abstract}

Keywords: Behavior, LGBT, Film

\begin{abstract}
ABSTRAK
Program CSR merupakan model pemberdayaan masyarakat, selain mengejar keuntungan juga mengejar kesejahteraan masyarakat disekitar wilayah kawasan kerja perusahaan serta pelestarian dunia seisinya. Tujuan penelitian mengetahui implementasi program pelibatan pemberdayaan masyarakat dalam meningkatkan citra perusahaan. Metode penelitian yang di gunakan deskriptif kualitatif. Pengumpulan data dari data primer berupa hasil observasi dan wawancara mendalam. Sedangkan data sekunder berupa studi kepustakaan dan dokumentasi. Data dianalisis menggunakan analisis SWOT. Hasil penelitian menunjukkan implementasi program pelibatan dan pemberdayaan masyarakat meningkatkan citra perusahaan.
\end{abstract}

Keywords: implementasi, program, pelibatan dan pemberdayaan masyarakat.

Raisatul Janah, 2019. Implementasi Program Pelibatan dan Pemberdayaan Masyarakat PT Tirta Investama Aqua Babakan Pari. 


\section{PENDAHULUAN}

Suatu perusahaan tidak berdiri sendiri pada suatu lingkungan apabila tidak selalu berhubungan dengan masyarakat sekitar dan menginginkan menjadi bagian dari masyarakat di tempat perusahaan berdiri. Dalam hal ini, hubungan masyarakat (Humas) harus mengimplementasikan komunikasi dua arah atau timbal balik antara perusahaan dengan masyarakat sekitar dengan metode membina hubungan baik dengan masyarakat sekitar (Effendy, 2004:137).

Semakin baik hubungan dengan masyarakat akan semakin baik pula citra perusahaan dimata masyarakat dan semangkin tinggi pula rasa bangga para pekerja dan staf pada perusahaanya (Iriantara, $2007: 32$ ).

Menurut Bill Canton (dalam Sukatendel, 1990:111) citra adalah kesan, perasaan, gambaran dari publik terhadap perusahaan. Kesan dengan sengaja menciptakan dari suatu obyek, orang atau organisasi (Soemirat dan Ardianto, 2007: 111-112).

Terminologi relationship management merupakan proses hubungan manajemen antara organisasi dengan publik internal dan eksternal. (Ledingham, 2003) mendefinisikan organisasi dan publikpublik kunci, tindakan salah satunya dapat mempengaruhi ekonomi, sosial, budaya, atau publik pada orang lain.

Menciptakan suasana yang selaras dan saling berkesinambungan antara perusahaan dengan masyarakat dirasa penting, khususnya warga sekitar perusahaan. Andi selaku manager CSR mengatakan, hal ini didasarkan masyarakat sekitar merupakan faktor utama dalam memberikan sebuah kontribusi yang baik serta memberikan citra yang baik pada perusahaan tersebut dimata masyarakat luas maupun para relasi perusahaan selaku manager CSR.

Salah satu metode dalam membina hubungan baik dengan masyarakat yaitu melalui program pemberdayaan masyarakat. Pembangunan masyarakat, amanat dari UUD 1945 menjadi tanggung jawab dan perhatian dari semua pihak baik pemerintah, perusahaan, maupun masyarakat. Program CSR model dari pemberdayaan masyarakat. Sehingga setiap perusahaan harus memegang prinsip $3 p$ (profit, people, dan planet) yang selain mengejar keuntungan juga harus mengejar kesejahteraan masyarakat di sekitar wilayah kawasan kerja perusahaan serta pelestarian dunia seisinya (Mardikanto, dalam Nasdian, 2014:56)

Tujuan penelitian untuk mengetahui analisis implementasi Program pemberdayaan masyarakat dalam meningkatkan citra perusahaan.

\section{MATERI DAN METODE}

Metode Penelitian yang digunakan yaitu metode deskriptif kualitatif, dimana peneliti mendeskripsikan atau mengkonstruksi wawancara mendalam terhadap subjek penelitian. Pengumpulan data primer dengan melakukan observasi dan wawancara mendalam. Data sekunder dikumpulkan dari catatan lapangan, foto, videotape, dokumen pribadi, catatan atau memo, dan dokumen resmi lainnya.

Teknik analisis data yang di gunakan analisis SWOT. (Rangkuti, 2009) SWOT singkatan dari lingkungan internal Strengths dan Weaknesses serta lingkungan eksternal Oppoturnities dan Threats yang di hadapi dalam dunia bisnis. Analisis SWOT membandingkan antara faktor eksternal peluang (Opportunities) dan ancaman (Threats) dengan faktor internal kekuatan (Strenghs) dan kelemahan (Weaknesses). 


\section{HASIL DAN PEMBAHASAN}

1. Analisis Swot Program Pelibatan dan Pemberdayaan Masyarakat

Faktor Internal dari Kekuatan (Strengths) yaitu meningkatkan perekonomian warga sekitar pabrik baik melalui program taman kehati, pengeloaan limbah atau rekrutmen tenaga kerja yang $75 \%$ nya adalah warga sekitar pabrik. Sedangkan faktor internal dari Kelemahan (Weaknes) yaitu Kurangnya partisipasi masyarakat dan pemerintah setempat, Karakteristrik masyarakat yang beragam, dan Mitra atau penyuluh yang bekerja sama dengan perusahaan bersifat kontrak sehingga tidak ada kelanjutan.

Faktor Eksternal dari Peluang (Oppurtunities) yaitu mengembangkan banyak program yang menarik dan bermanfaat bagi masyarakat, antusiasme masyarakat dan pemerintah sekitar. Sedangkan faktor internal dari Ancaman (Threats) yaitu program yang diberikan perusahaan tidak berlanjut, ketergantungan masyarakat dan pemerintah sekitar terhadap program CSR dari perusahaan.

2. Citra Perusahaan PT Tirta Investama Aqua

Faktor Internal dari Kekuatan( Strengths) yaitu mengembangkan banyak program yang sangat menarik dan bermanfaat bagi masyarakat, antusiasme pemerintah dan masyarakat sekitar. Sedangkan faktor eksternal dari Kelemahan (Weaknes), adanya miss komunikasi dan perbedaan presepsi, sumber daya manusia dari CSR yang kurang.

Faktor Eksternal dari Peluang (Oppurtunities) yaitu mempertahankan kerjasama dengan komunitas-komunitas, stakeholder, mitra, dan masyarakat setempat serta konsisten terhadap visi dan misi untuk program yang di usung. Sedangkan faktor eksternal dari Ancaman (Threats) yaitu ditunggangi oleh kepentingan-kepentingan lain, tidak tepat sasaran apa yang dibutuhkan masyarakat dengan program yang di berikan CSR dan menurunya kepercayaan masyarakat terhadap perusahaan.

\section{KESIMPULAN DAN IMPLIKASI}

\section{Simpulan}

Implementasi program pelibatan dan pemberdayaan masyarakat berjalan baik dan efektif dengan partisipasi dari masyarakat Babakan Pari sehingga dapat membentuk citra positif perusahaan.

\section{Implikasi}

1. Corporate Social Responsibility (CSR) adalah suatu jembatan atau penghubung antara perusahaan dengan masyarakat, stakeholder dan mitra yang diimplementasikan agar program pelibatan dan pemberdayaan masyarakat dalam membangun hubungan baik berjalan dengan efektif. Hubungan yang dijalin dan dibina dengan baik akan berpengaruh terhadap citra yang baik. Bill Canton (dalam Sukatendel, 1990:111)

2. Pihak CSR maupun staf lain mengimplementasikan hubungan baik dengan masyarakat untuk menumbuhkan citra perusahaan. Bagi mahasiswa/mahasiswi Public Relations dalam membina hubungan baik harus ditanamkan sejak dini dalam hati nurani sehingga tidak akan ada miss komunikasi ketika berprofesi sebagai Humas/CSR.

\section{DAFTAR PUSTAKA}

Ardianto, Elvinaro. 2007. Public Relations Praktis. Bandung: Widya Padjajaran 2010. Metodologi Penelitian untuk

Public Relations, Kuantitatif dan Kualitatif. Bandung: Simbiosa Rekatama Media 
Effendy, Onong Uchjana. 2004. IImu Komunikasi Teori dan Praktek. Bandung: PT Remaja Rosdakarya

Rangkuti, Freddy. 2015. Teknik membedah kasus bisnis Analisis SWOT. Jakarta: PT Gramedia Pustaka Utama

Iriantara, Yosal. 2007. Community Relations Konsep dan Aplikasinya. Bandung: Simbiosa Rekatama Media 